\title{
Biocontrol activity of microoganisms on Botrytis isolates from vineyards
}

\section{Actividad de biocontrol de microorganismos sobre aislados de Botrytis provenientes de viñedos}

JUÁREZ-CAMPUSANO, Yara-Suhan†, CHÁVARO-ORTÍZ, María del Socorro, SOTO-MUÑOZ, Lourdes and PACHECO-AGUILAR, Juan-Ramiro*

Universidad Autónoma de Querétaro, Facultad de Química, Cerro de las campanas s/n, col. Las Campanas, C.P. 76040. Santiago de Querétaro Qro.

ID $1^{\text {st }}$ Author: Yara Suhan, Juárez-Campusano / ORC ID: 0000-0003-0886-5466, CVU CONACYT ID: 710264

ID $1^{\text {st }}$ Coauthor: María del Socorro, Chávaro-Ortiz / ORC ID: 0000-0013-7516-1675, CVU CONACYT ID: 289699

ID $2^{\text {nd }}$ Coauhor: Lourdes, Soto-Muñoz / ORC ID: 0000-0001-8573-1600, CVU CONACYT ID: 160058

ID $3^{\text {rd }}$ Coauthor: Juan Ramiro, Pacheco-Aguilar / ORC ID: 0000-0001-8365-4488, CVU CONACYT ID: 87499

DOI: $10.35429 / J A N R E .2020 .7 .4 .6 .10$

Received September 21, 2020; Accepted November 09, 2020

\begin{abstract}
Botrytis cinerea causes postharvest fruit rot of an infinity of crops, the infective capacity is due to its physiological diversity that shown, even inside the same crop. For its control, the use of antagonistic microoganisms is emerging as a sustainable option. In the present work, 40 Botrytis isolates from three vineyards were characterized by their ability to infect grape fruit (Thomson Seedless), the results showed that all produced lesions diameters from 6.5 to $22.2 \mathrm{~mm}$. Ten of these isolates that presented differences in terms of their virulence, were subject to in vitro antagonism test, using the yeasts Metschnikowia sp. NB9 and FLL17 (Kodamaea sp. FLL17 and the bacteria FR4B12 Bacillus sp. R4B12 from must and flower and fruit, respectively. The results showed that, on average, FRB412 had the highest inhibitory activity on the growth of Botrytis strains, exhibiting mycelial growth inhibition percentages from 51 to $81 \%$, followed by FLL17 (21 to $53 \%$ ) and NB9 (15 to $51 \%)$. In conclusion, the three study strains have different ranges of biocontrol on Botrytis, whose application could reduce gray rot in grapes.
\end{abstract}

Gray rot, Vineyards, Virulence

\begin{abstract}
Resumen
Botrytis cinera causa la podredumbre de frutos poscosecha de una gran cantidad de cultivos, su capacidad infectiva es debido a la diversidad fisiológica que presenta, inclusive dentro del mismo cultivo. Para su control, el uso de microorganismos antagonistas, se perfila como una opción sustentable. En el presente trabajo, se caracterizaron 40 aislados de Botrytis provenientes de tres viñedos, por su capacidad para infectar frutos de uva de mesa (Thompson Seedless), encontrando que todos generaron diámetros de lesión en un rango del 6.5 a $22.2 \mathrm{~mm}$. Diez de estas cepas, seleccionadas por presentar diferencias en cuanto a su virulencia fueron sujetas después a ensayos de antagonismo in vitro, empleando las levaduras: Metschnikowia sp. NB9 y FLL17 Kodamaea sp. FLL17 y, la bacteria Bacillus sp. FR4B12 provenientes de mosto, flor y fruto, respectivamente. Los resultados mostraron que, en promedio, FRB4B12 tuvo la mayor actividad inhibitoria sobre el crecimiento de las cepas de Botrytis, exhibiendo porcentajes de inhibición del micelio en un rango de 51 al $81 \%$, seguido por FLL17 (21 al $53 \%$ ) y NB9 (15-51\%). En conclusión, las tres cepas de estudio poseen diferentes rangos de biocontrol sobre Botrytis, cuya aplicación pudiera reducir la podredumbre gris en uva.
\end{abstract}

Podredumbre gris, Viñedos, Virulencia

Citation: JUÁREZ-CAMPUSANO, Yara-Suhan, CHÁVARO-ORTÍZ, María del Socorro, SOTO-MUÑOZ, Lourdes and PACHECO-AGUILAR, Juan-Ramiro. Microorganism biocontrol activity on Botrytis isolates from vineyards. JournalAgrarian and Natural Resource Economics. 2020. 4-7: 6-10

\footnotetext{
* Correspondence to Author (email: juanramiro29@yahoo.com.mx)

$\dagger$ Researcher contributing as first author.
} 


\section{Introduction}

Gray rot is a disease caused by the Botrytis cinerea fungus, which is widely distributed worldwide, and has caused the loss of a variety of crops at the post and pre-harvest level (Keller, 2015, Khazaeli et al., 2012). During the infective process, the $B$. cinerea conidia produce a germ tube that penetrates the host's cuticle, then through the enzymatic production of pectinases, cellulases and hemicellulases they begin to degrade the plant tissues (Nakajima, \& Akutsu, 2014; Abo -Elyousr et al., 2020), which can include stems, leaves and fruits (Fillinger and Elad, 2016),

It is worth mentioning that Botrytis during infection is capable of taking advantage of reactive oxygen species, produced as the first defense response in plants, in order to generate a greater degree of damage (Dean et al., 2012). Among the factors in the microenvironment of the infection, the $\mathrm{pH}$ is decisive for the development of the disease, this fungus being able to modify its environment through the production of organic acids, which gives this fungus the ability to infect, from grapes with a $\mathrm{pH}$ of 3 to 4, to pumpkins with a $\mathrm{pH}$ of 6 to 7 (Rascle et al., 2018).

The environmental isolates obtained from Botrytis exhibit variability in the damage they exert on their hosts, Acosta et al. (2018), report different degrees of severity in vine leaf and fruit infection, using Botrytis isolates from vineyards of six wine-producing regions. This variability may be due to intrinsic and extrinsic factors of the strains and of the hosts. Which allows to continue investigating the physiological differences that it presents in each particular crop.

Biological control (biocontrol) has been implemented in recent years, as an alternative tool to chemical control, in order to reduce the negative impact caused by the latter on agroecosystems, human health and soil fertility (Lemanceau et al., 2015).

Biological control uses biotic
interactions that naturally occur between
pathogenic and beneficial microorganisms,
which are coexisting in plant tissues.

Among the most frequent interaction is antagonism, in which one organism prevents the development or growth of another (Bagnères \& Hossaert-McKey, 2020; Janisiewicz and Korsten, 2002), either through the production of enzymes, antibiotics, lipopeptides, siderophores, or by competition for space and nutrients, properties that have been observed in most biocontrol agents (Bagnères \& HossaertMcKey, 2020; Calvo-Garrido et al., 2013; Bernard et al., 2012).

In the present work, Botrytis strains from three vineyards in the state of Queretaro, Mexico, were isolated and characterized. In order to find differences in terms of their ability to infect fruits and their susceptibility to biocontrol, using two yeast strains and one bacterium, as antagonists.

\section{Materials and methods}

\section{Microbial antagonists}

The antagonist microorganisms used in the present study were the yeasts Metschnikowia sp. NB9 and Kodamaea sp. FLL17 obtained from a fermentation must and apple blossom, respectively. Additionally, the bacterium Bacillus sp. FR4B12, isolated as apple epiphyte. All the isolates belong to the Laboratory of Plants and Agricultural Biotechnology of the Faculty of Chemistry of the Autonomous University of Querétaro, and have been tested against Botrytis strains in previous trials (Barcenas and Pacheco, 2019; JuárezCampusano et. al., 2020).

\section{Obtaining isolates of $B$. cinerea}

During 2017, three vineyards located in the state of Querétaro, Mexico, were sampled. One vineyard located in the Municipality of El Marqués (A) and two more located in the Municipality of Ezequiel Montes (B and C). From the three vineyards, grape samples of three varieties ('Merlot', 'Tempranillo' and 'Syrah') were taken at random, later, the fruits were taken to the laboratory and were placed in humid chambers at $4{ }^{\circ} \mathrm{C}$ for 15 days to isolate the Botrytis strains, which were subsequently subcultured in Petri dishes with potato dextrose agar (PDA) until obtaining a pure culture. Consecutively, the fungus species was determined through the morphology of the mycelium and spores according to Khazaeli et al., (2012).

JUÁREZ-CAMPUSANO, Yara-Suhan, CHÁVARO-ORTÍZ, María del Socorro, SOTO-MUÑOZ, Lourdes and PACHECO-AGUILAR, JuanRamiro. Microorganism biocontrol activity on Botrytis isolates from vineyards. Journal-Agrarian and Natural Resource Economics. 2020 


\section{Virulence of isolates}

From the isolates obtained from $B$. cinerea, fruit tests were carried out to determine the infective capacity on table grape cv. 'Thompson Seedless'. For this, the fruits were washed, disinfected and dried as indicated by SandovalChávez et al., (2011). For the infection test, wounds were made in the grape fruits where $10^{3}$ spores or active mycelium of $72 \mathrm{~h}$ (three groups of three fruits) were inoculated. At the end of the seven-day period, the size of the lesion was recorded using a vernier, classifying the strains according to their virulence. Botrytis $\mathrm{BC} 152$ was used as a control strain, which is an isolate from commercial table grape 'Thompson Seedless'.

\section{Biocontrol tests}

Of the Botrytis isolates, ten were selected for their differences in the degree of infectionvirulence, to perform in vitro antagonism assays by dual culture.

A $7 \mathrm{~mm}$ disc of active mycelium was placed in the center of a yeast nutrient dextrose agar (NYDA) and allowed to grow $24 \mathrm{~h}$ at $35^{\circ} \mathrm{C}$. Subsequently, a roast of each antagonist was inoculated $1 \mathrm{~cm}$ from the edge of the Petri dish. Inhibition measurements were performed with a T\&O Model 57-016-220 Digital Vernier until the control was fully grown. All tests were performed in triplicate.

\section{Statistical analysis}

All data were subjected to a test of normality and homoscedasticity, and subsequently subjected to an analysis of variance. (ANOVA). In the biocontrol tests, the values obtained were expressed as the percentage of inhibition of the mycelium, according to the formula proposed by Chen et, al. (2018). The data were transformed to angular degrees to submit them to an analysis of variance, and to a Tukey test of means analysis with $99 \%$ confidence. All analyzes were carried out in the $\mathrm{R}$ program version 4.0.3.

\section{Results}

\section{Obtaining isolates of $B$. cinerea}

40 Botrytis isolates were characterized. From the different vineyards, 15 were obtained from A, 11 from $B$ and 14 from $C$, there were no significant differences in number between them.
Although initially it was considered that, due to the cultural and chemical management in the different places, there would be differences, it seems that it was not a relevant factor. On the other hand, when comparing according to the grape variety, it was found that 27 of these came from the 'Merlot' variety, 11 from 'Syrah' and the rest from 'Tempranillo'. This shows, in part, that, despite being the same type of host, the responses can be variable due to particular factors in them (Nakajima, \& Akutsu, 2014).

\section{Virulence of isolates}

Regarding the degree of damage produced by the different isolates on grape fruits, it was found that most caused lesions in a range of 6.5 to 22.2 $\mathrm{mm}$ in diameter, with differences between the strains (ANOVA, Tukey $\mathrm{p}<0.01$ ). In general, it was found that the BC136 isolate obtained from the 'Syrah' grape from vineyard $\mathrm{C}$, was the one that showed the greatest damage to the grape, with an average $22.2 \mathrm{~mm}$, in contrast to $\mathrm{BC} 154$ isolated from the 'Merlot' grape, from Vineyard $\mathrm{B}$, which produced a minimal lesion of $6.5 \mathrm{~mm}$. This shows the variety of degrees of damage that a species of fungus can have, since different types of characters can be found among the isolates, such as the production of enzymes, the capacity and speed of conidia formation, and the same response of the host to intervene in the virulence process (Rascle et al., 2018; Nakajima, $\&$ Akutsu, 2014).

\section{Biocontrol tests}

Of the strains resulting from the fruit injury test, ten isolates that presented varying ranges of injury were selected and subjected to a dual antagonism test in vitro with the yeast NB9 and FLL17 and the bacterium, FR4B12. Fig. 1 shows the differences that the microorganisms exerted on the Botrytis strains (Figure 1). FR4B14 inhibited the different strains in a greater amount in a range from 51 to $81^{\mathrm{a} \%}$, and FLL17 and NB9 yeasts, in ranges of $21-53^{\mathrm{b}} \%$ and $15-51^{\mathrm{c}} \%$ respectively (ANOVA, Tukey $\mathrm{p}<0.01,{ }^{\mathrm{a}},{ }^{\mathrm{b}},{ }^{\mathrm{c}}$ Same letters, no significant differences) (Graph $1)$. 

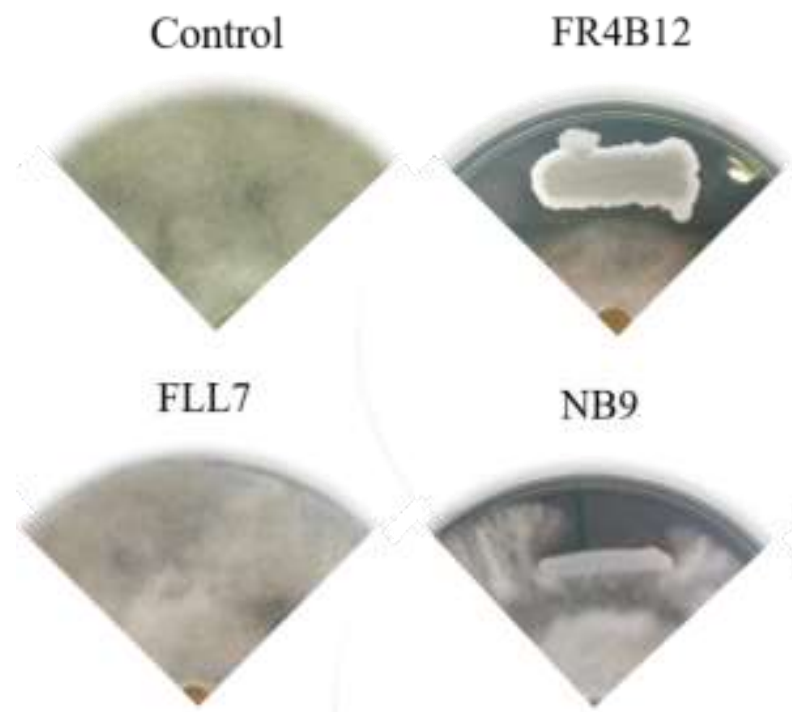

Figure 1 Biocontrol in dual culture of Botrytis BC155 using the different antagonists

On the other hand, it was also observed that the degree of biocontrol varies for each strain, of which were used for this test, BC76 (isolated from 'Merlot' grape, from vineyard A) resulted with the lowest percentages of inhibition $\left(35 \%^{\mathrm{b}}\right)$, while $\mathrm{BC} 155$ (isolated from Merlot, from vineyard B) exhibited the highest percentages of inhibition $\left(81 \%^{\mathrm{a}}\right)$. The remaining BC59, 63, 64, 73, 137, 145, 147, 152 and 154 were intermediate and similar to each other $a b$ (ANOVA, Tukey $\mathrm{p}<0.01,{ }^{\mathrm{a}},{ }^{\mathrm{b}},{ }^{\mathrm{c}}$ Equal letters, no significant differences) (Graph 2).

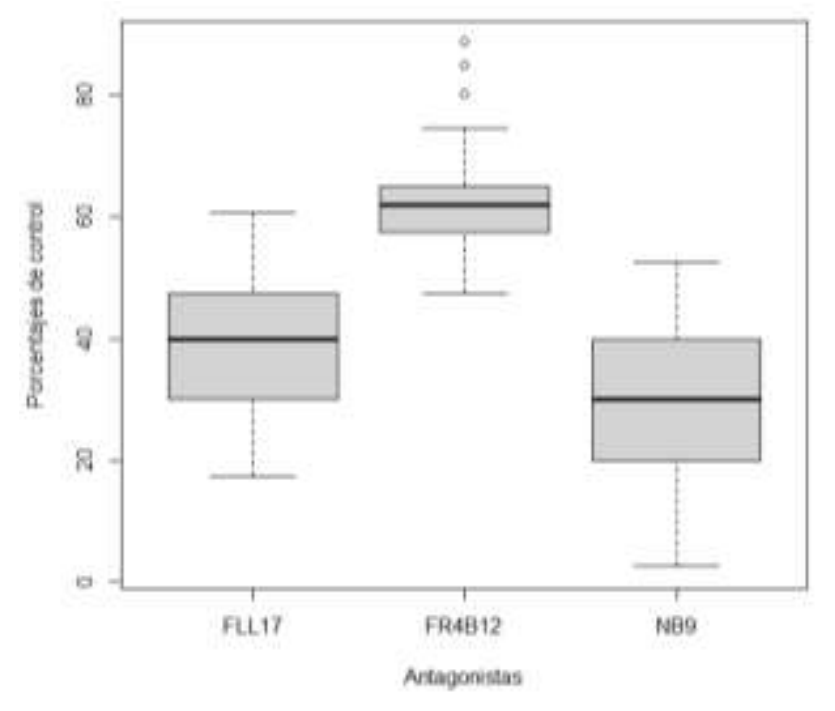

Graphic 1 Biocontrol effectiveness of antagonist microorganisms tests on Botrytis isolates

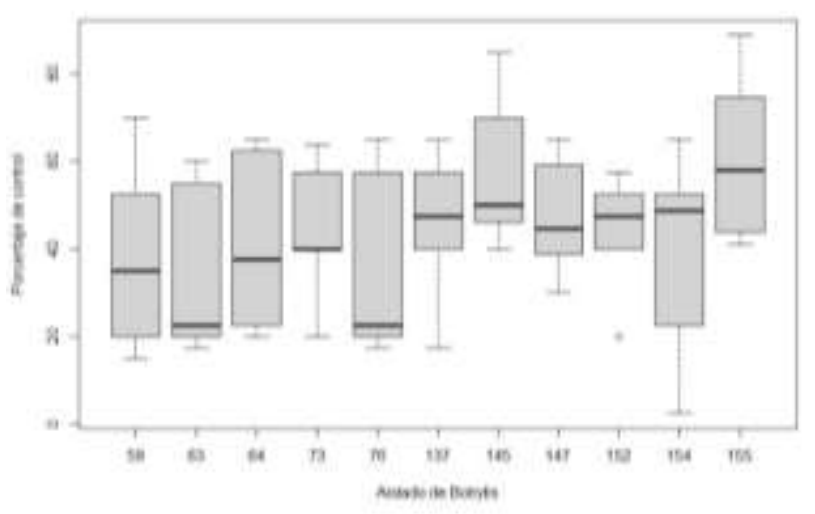

Graphic 2 Biocontrol among Botrytis cinérea isolates

Comparing the results of both trials, we found that although BC76 showed minimal lesions in fruit $(9.76 \mathrm{~mm})$, it was the least inhibited in the antagonism trials, while $\mathrm{BC} 155$ showed higher lesion values $(14.5 \mathrm{~mm})$ compared to BC76, was mostly inhibited by antagonists.

\section{Acknowledgments}

The authors thank the National Council of Science and Technology for the financing for the realization of this project "Biological Control of Botrytis sp. using yeasts with oenological potential on vine "PN2016 / 3930.

\section{Conclusions}

This study shows that different Botrytis isolates from three vineyards in the state of Querétaro, present physiological variations in terms of their infective capacity of table grapes (Thompson Seedless'), finding highly infective isolates in the three study sites.

The biocontrol capacity on the Botrytis isolates was mainly carried out by the bacteria obtained from apple fruit, which indicates the versatility of the biocontrol agents to act in cultures other than those that were isolated.

The Botrytis isolates that caused the least lesions in the fruit, showed in biocontrol tests, low and intermediate inhibition values, which could indicate the establishment of resistant strains. 


\section{References}

Abo-Elyousr, K. A., Alamri, S. A., Hussein, M. M., Hassan, M. A., Abd El-Fatah, B. E., \& Hashem, M. (2020). Molecular disparities among Botrytis species involved in onion umbel blight disease and its management using Bacillus subtilis PHYS7. Egyptian Journal of Biological Pest Control, 30(1), 1.

Acosta Morel, W., Marques-Costa, T. M., Santander-Gordón, D., Anta Fernández, F., Zabalgogeazcoa, I., Vázquez de Aldana, B. R., Sukno, J. M., Díaz, D. \& Benito, E. P. (2019). Physiological and population genetic analysis of Botrytis field isolates from vineyards in Castilla y León, Spain. Plant Pathology, 68(3), 523-536.

Bagnères, A. G., \& Hossaert-McKey, M. (2020). Ecología química. ISTE Group.

Bernard, E., Larkin, R.P., Tavantzis, S., Erich, M.S., Alyokhin, A., Sewell, G., Lannan, A., Gross, S.D. 2012. Compost, rapeseed rotation, and biocontrol agents significantly impact soil microbial communities in organic and conventional potato production systems. Applied Soil Ecology 52, 29-41

Calvo-Garrido, C., Elmer, P.A.G., Viñas, I., Usall, J., Bartra, E., Teixidó, N. 2013. Biological control of botrytis bunch rot in organic wine grapes with the yeast antagonist Candida sake CPA-1. Plant Pathology 62, 510-519.

Chen, P. H., Chen, R. Y., \& Chou, J. Y. (2018). Screening and evaluation of yeast antagonists for biological control of Botrytis cinerea on strawberry fruits. Mycobiology, 46(1), 33-46.

Dean, R., Van Kan, J.A.L., Pretorius, Z.A., Hammond-Kosack, K.E., Di Pietro, A., Spanu, P.D., Rudd, J.J., Dickman, M., Kahmann, R., Ellis, J. 2012. The Top 10 fungal pathogens in molecular plant pathology. Molecular Plant Pathology 13, 414-430.

Fillinger, S., Elad, Y. (Eds.) 2016. Botrytis-the fungus, the pathogen and its management in agricultural systems. Springer International Publishing. London, UK

Janisiewicz, W.J., Korsten, L. 2002. Biological control of postharvest diseases of fruits. Annual Review of Phytopathology 40, 411-441.
Keller, M. 2015. The Science of Grapevines: Anatomy and Physiology. Academic Press. Prosser, WA, USA. 522 pp.

Khazaeli, P., Zamanizadeh, H., Morid, B., Bayat, H. 2012. Morphological and Molecular Identification of Botrytis cinerea Causal Agent of Gray Mold in Rose Greenhouses in Centeral Regions of Iran. International Journal of Agricultural Science and Research 1, 19-24.

Lemanceau, P., Maron, P. A., Mazurier, S., Mougel, C., Pivato, B., Plassart, P., Ranjard, L., Revellin, C., Tardy, V., Wipf, D. 2015. Understanding and managing soil biodiversity: a major challenge in agroecology. Agronomy for Dustainable Development, 35(1), 67-81.

Nakajima, M., \& Akutsu, K. (2014). Virulence factors of Botrytis cinerea. Journal of General Plant Pathology, 80(1), 15-23.

Rascle, C., Dieryckx, C., Dupuy, J. W., Muszkieta, L., Souibgui, E., Droux, M., ... \& Poussereau, N. (2018). The $\mathrm{pH}$ regulator PacC: a host-dependent virulence factor in Botrytis cinerea. Environmental microbiology reports, 10(5), 555-568.

Sandoval-Chávez, R. A., Martínez-Peniche, R. Á., Hernández-Iturriaga, M., FernándezEscartín, E., Arvizu-Medrano, S., \& SotoMuñoz, L. (2011). Control biológico y químico contra Fusarium stilboides en pimiento morrón (Capsicum annuum L.) en poscosecha. Revista Chapingo. Serie horticultura, 17(2), 161-172. 